Contribution of the temperate forests to the world's carbon budget

\author{
Heath, L.S.
}

Kluwer

1993

Heath, L.S. et al. 1993. Contribution of the temperate forests to the world's carbon budget.

Water, Air, and Soil Pollution 70:55-69.

http://hdl.handle.net/1975/322

Downloaded from Helda, University of Helsinki institutional repository.

This is an electronic reprint of the original article.

This reprint may differ from the original in pagination and typographic detail.

Please cite the original version. 


\section{CONTRIBUTION OF TEMPERATE FORESTS TO THE WORLD'S CARBON BUDGET}

LINDA S. HEATH

PEKKA E. KAUPPI

PETER BURSCHEL

HEINZ-DETLEV GREGOR

ROBERT GUDERIAN

GUNDOLF H. KOHLMAIER

SUSANNE LORENZ

DIETER OVERDIECK

FLORIAN SCHOLZ

HARALD THOMASIUS MICHAEL WEBER
USDA Forest Service, Global Change Research Program, Northeastern Forest Expt. Station, P. O. Box 6775, Radnor, PA, 19087, USA

Finnish Forest Reseurch Institute, Unionin':atu 40 A, SF-00170 Helsinki, Finland

Universität München, Lehrstuhl f. Waldbau und

Forsteinrichtung, Hohenbachernstraße 22, W-8050 Freising, Germany

Federal Environmental Agency of Germany, Bismarckplatz 1, W-1000 Berlin 33, Germany

Institut für angewandte Botanik, Universität Essen,

Universitätsstr. 5, W-4300 Essen, Germany

Institut für phys. Chemie der Universitüt Frankfurt, W-6000

Frankfurt 60, Germany

Institute for World Forestry, Federal Research Centre for

Forestry and Forest Products, Leuschnerstr. 91, W-2050

Hamburg 80, Germany

TU Berlin, Institute of Ecology, Ecology of Woody Plants, Königin-Luise-Str. 22, W-1000 Berlin 33, Germany BFA für Forst- und Holzwirtschaft, Institüt $f$. Forstgenetik, Sicker Landstr. 2, W-2070 Großhausdorf 2, Germany Auf der Bismarckhöhe 24, O-8223 Tharandt, Germany Lehrstuhl f. Waldbau und Forsteinrichtung, Hohenbachernstr. 22, W-8050 Freising, Germany

Abstract. Temperate forests currently cover about $600 \mathrm{MHa}$, about half of their potential. Almost all these forests have been directly impacted by humans. The total living biomass in trees (including roots) was estimated to contain $33.7 \mathrm{Gt} \mathrm{C}$. The total $\mathrm{C}$ pool for the entire forest biome was estimated as $98.8 \mathrm{Gt}$. The current net sink flux of biomass was calculated at $205 \mathrm{Mt} \mathrm{yr}^{-1}$, with a similar amount removed in harvests for manufacture into various products. The major cause of this $\mathrm{C}$ sink is forest regrowth. Forest regrowth is possible because fossil fuels are the major source of energy in temperate countries, instead of fuelwood. Future $\mathrm{C}$ in these forests will be greatly influenced by human activity. Options to sequester more $\mathrm{C}$ include conservation of forest resources, activities that increase forest productivity such as adopting rotation ages to optimize $\mathrm{C}$ production, afforestation, improvement of wood utilization, and waste management. 


\section{Introduction}

Temperate forests do not form a uniform belt around the globe, but exist in large blocks of discontinuous forest cover on five continents surrounded by extensive areas of prairie, steppe and desert (Figure 1). We define temperate forest as those forests in the mid-latitudes that are not included in the tropics or in boreal forests. The forest composition is diverse with deciduous broadleaved and mixed broadleaved/coniferous, evergreen and warm temperate mixed broadleaved, and cold-temperate coniferous types. The temperate forests in western Canada and Scandinavia were included in the boreal forest assessment for convenience.

North America currently contains $60 \%$ of the present area of temperate forest, Russia and Europe about $12 \%$ each, with the remainder scattered throughout the rest of Asia, Australia, New Zealand and South America. Virtually all temperate forests have been exploited and directly impacted by human beings, with the exception of those in major mountain systems. The forests share the landscape with agricultural land, pastures and urban areas, and seldom cover more than $40 \%$ of the land area in any one of the forest regions. Japan and some of the U.S. are exceptions with 50 to $70 \%$ of the area in forest.

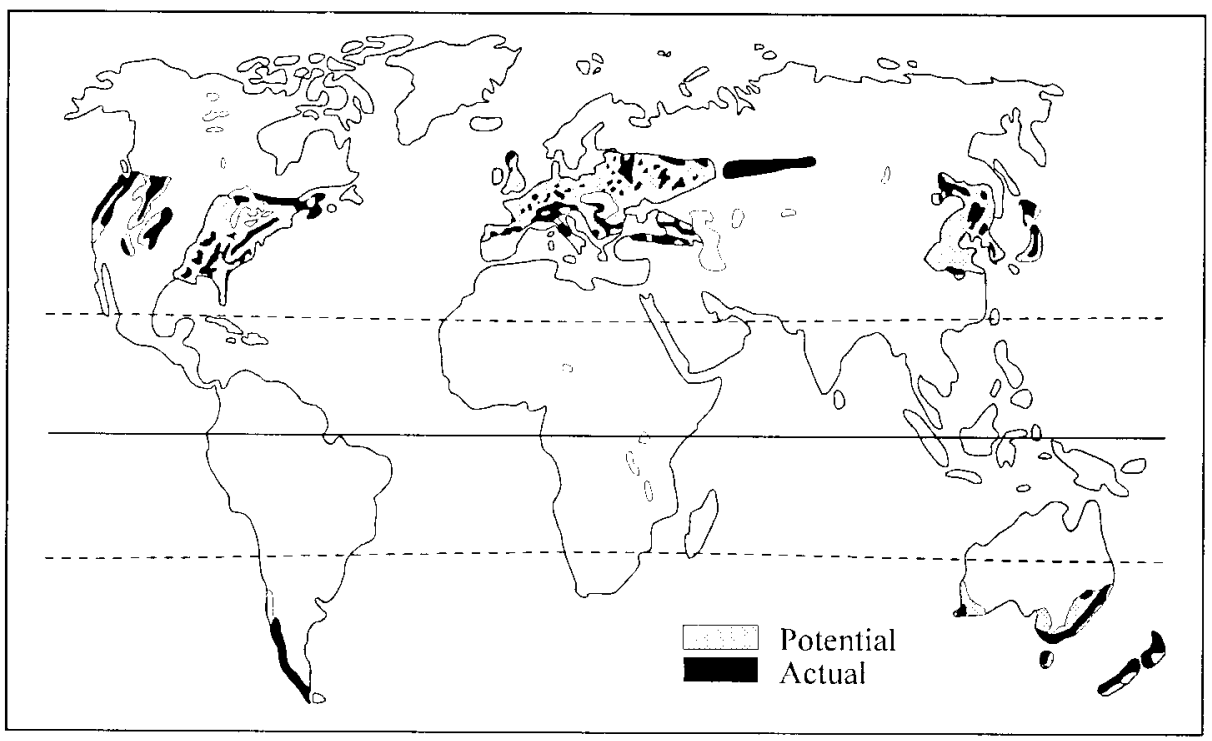

Figure 1. Potential and actual area of temperate forests (after Deutscher Bundestag [1990]). 


\section{Carbon Budget of Temperate Forests}

\subsection{METHODOLOGY OF CALCULATING}

Figure 2 illustrates the $\mathrm{C}$ pools and fluxes in a forest. We distinguish one input flux, $F_{a b}=F_{n p p}$, which is the annual net primary production and two output fluxes: $F_{h a}$, which is the flux from the decomposition of litter and soil, also called heterotrophic respiration, and $F_{w a}$, which in a natural system is equal to $F_{b w}$, the disturbance flux through catastrophic events, like fire, storm, insect infestation and also containing the component of herbivory feeding. As indicated in Figure 2, the three fluxes connecting the biota with the atmosphere determine whether the living biota and soils act as a source or a sink for atmospheric $\mathrm{CO}_{2}$ or whether a steady state exists.

\subsection{PRESENT POOLS AND FLUXES}

Estimates for the pools and fluxes of $\mathrm{C}$ in aboveground biomass of temperate forests can be obtained from statistics on standing stock on forested land, and related wood increment and net primary prcductivity. For consistency, a simple methodology was chosen to calculate $\mathrm{C}$ pools and fluxes for most regions within the biome. The forest land areas were taken from UN-ECE/FAO statistics (1992) and other sources. Each hectare of temperate forest was assumed to contain 57.1 tons of $\mathrm{C}$ in living vegetation, which is the average $\mathrm{C}$ on a hectare from the largest individual region, the U.S. Soil was assumed to contain twice as much $\mathrm{C}$ as the living biomass. The net primary productivity was estimated corresponding to a net annual increment of $5 \mathrm{~m}^{3} \mathrm{ha}^{-1} \mathrm{yr}^{-1}$ of stemwood. Stemwood was assumed to contribute $70 \%$ to the net primary productivity. Net storage in living biomass was estimated by assuming that fellings and natural losses account for $80 \%$ of the net primary production. Removal statistics were used to estimate the $\mathrm{C}$ transfer to forest products. Results are displayed in Table 1.

The total forested area assessed as temperate forests consisted of $600 \mathrm{Mha}$. This excluded forests in western Canada (130 Mha), an area considered by the boreal forest working group. The total living biomass in trees (above- and belowground) was estimated to contain $33.7 \mathrm{Gt} \mathrm{C}$. The total $\mathrm{C}$ pool of temperate forest ecosystems was estimated as $98.8 \mathrm{Gt}$.

Net primary production was estimated as $892 \mathrm{Mt} \mathrm{yr}^{-1}$. As $20 \%$ of it was assumed to accumulate in forests, a sink flux of $205 \mathrm{Mt} \mathrm{yr}^{-1}$ was sequestered in living trees. This estimate is similar to previous estimates by Armentano and Ralston (1980) and Sedjo (1992), after adjusting for differences in definitions of temperate forests. For those countries with available statistics, we calculated an additional $192 \mathrm{Mt} \mathrm{C} \mathrm{yr}^{-1}$ was removed in harvests. 


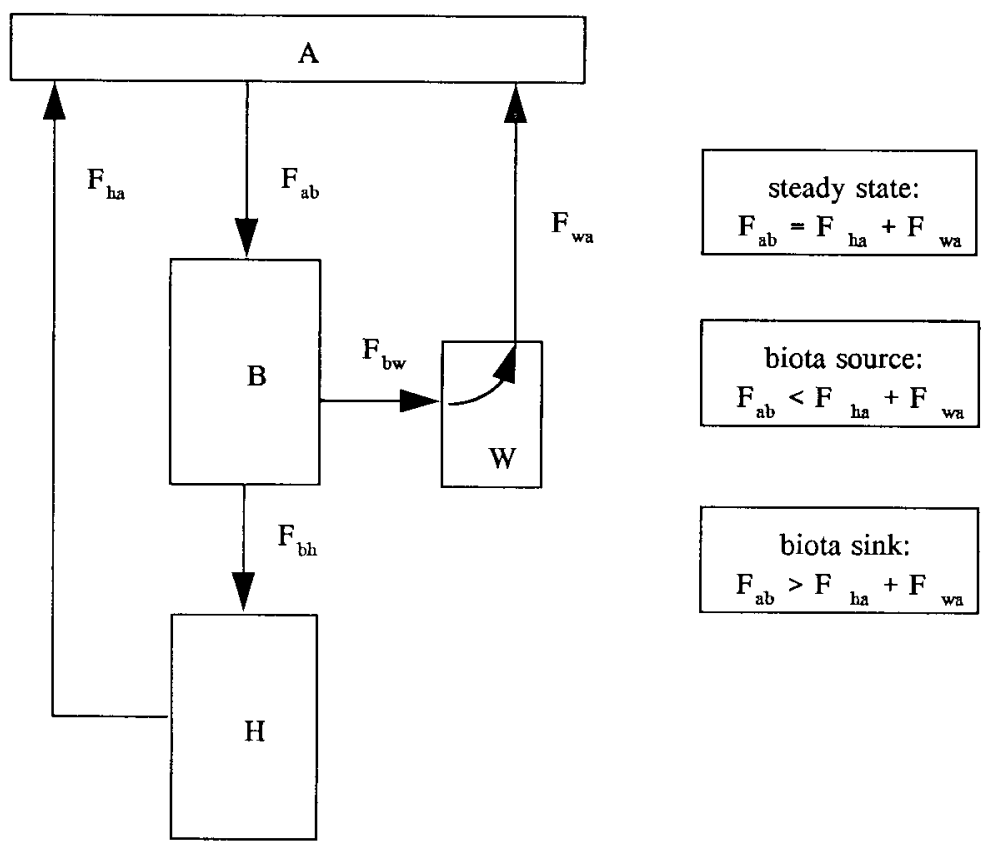

Pools:

$A=C$ in atmosphere

$\mathrm{B}=\mathrm{C}$ in biota (trees and understory)

$\mathrm{H}=\mathrm{C}$ in litter and humus of soils

$\mathrm{W}=\mathrm{C}$ in wood products of human society

Fluxes:

$\mathrm{F}_{\mathrm{ab}}=\mathrm{F}_{\text {NPP }} \quad$ : net primary production (leaves, stems, branches, roots, fruits)

$\mathrm{F}_{\mathrm{bh}} \quad:$ litterfall

$\mathrm{F}_{\mathrm{ha}} \quad:$ heterotrophic (animal/microbial) respiration of litter and humus

$\mathrm{F}_{\mathrm{bw}}=\mathrm{F}_{\text {wa }} \quad$ : with $\mathrm{W}=0$ in natural systems

$=\mathrm{F}_{\text {disturb }}:$ disturbance flux (fire, insects, storms) in natural systems

$\mathrm{F}_{\mathrm{bw}}=\mathrm{F}_{\text {harvest }}$ : harvest in managed and natural forests, roundwood production

$\mathrm{F}_{\mathrm{wa}}=\mathrm{F}_{\text {decay }} \quad$ : decay of wood products, burning of wood and biomass

Figure 2. Systems diagram for pools and fluxes in temperate forests including wood products in human society. 


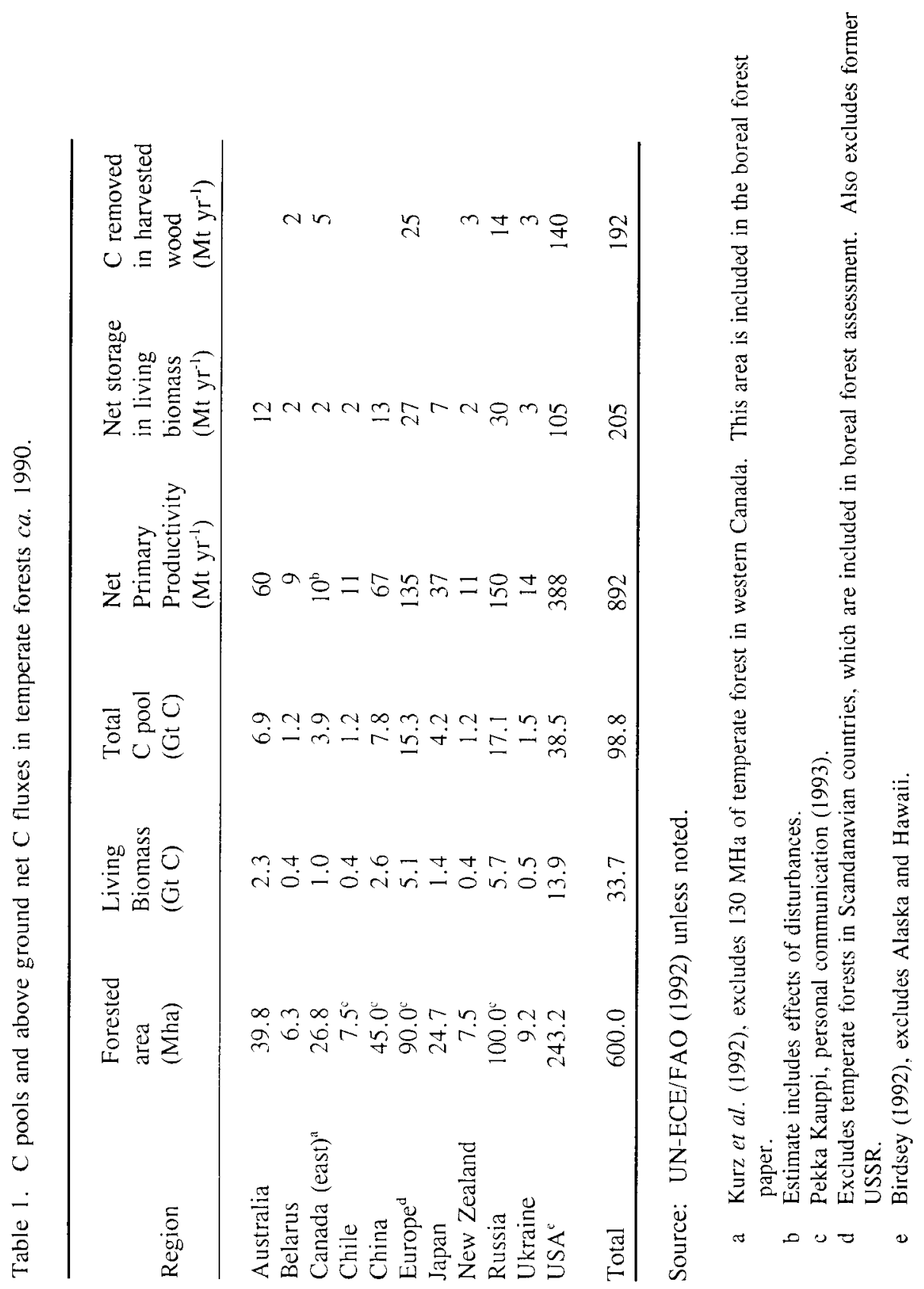




\section{Trends in Net Carbon Flux Over Time}

The trends of net $\mathrm{C}$ flux over time may be estimated qualitatively. Past net $\mathrm{C}$ fluxes can be inferred from land use histories. We concentrate on Europe and the United States where we have more information. Currently, temperate forests are a $\mathrm{C}$ sink because of area expansion and forest regrowth. Future trends are uncertain even if no climate change is assumed because of heavy human demands on these forests.

\subsection{PAST}

\subsubsection{History of European forests}

Without human impact more than $90 \%$ of Central Europe would be covered by forests. The first clearing for pasture and primitive agriculture took place during the Bronze Age mostly on lowlands with fertile soils and mild climate. By the 12 th century, widespread clearing of forests for agriculture and harvesting for fuelwood had occurred. Forest cover was reduced to $30 \%$ (Deutscher Bundestag, 1990). In the early $1800 \mathrm{~s}$, much natural forest was converted to even-aged coniferous monocultures in response to the industrial revolution and increased demand for wood. However, problems with this type of management have led recently to silvicultural practices which favor deciduous trees. Forest area has been increasing since the beginning of the 20th century. Thus, European forests were a weak $\mathrm{CO}_{2}$ source in the 19 th century, and a weak sink in the 20 th century.

\subsubsection{History of U.S. forests}

By the early 1800 s, only about $15 \%$ of pre-colonial forest in the continental U.S. had been cut, mainly in the East (Heath and Birdsey, this volume). Forests were rapidly cleared for agriculture and wood products, and by 1850 , approximately $65 \%$ of the forests remained. Harvesting and land clearing continued at a rapid rate through the early 20 th century as the U.S. land base and population grew. In the eastern U.S., the area of forestland has increased since the mid-1900s as land used for agriculture was abandoned and reverted to forests.

Harvesting was not the only influence on the forest during these two centuries. Wildfires have played a significant role in the landscape, unlike Europe, where fires are of only local importance. Wildfires annually consumed an estimated 8 to 20 Mha before 1930 (MacCleery, 1992). Repeated wildfires on the same areas left an estimated $32.4 \mathrm{MHa}$ unstocked in the 1920s. After fires began to devastate lives and property in communities, strong fire programs were instituted. By 1960 and through the present, the area burned annually was reduced to about $10 \%$ of pre-1930 levels.

Based on this history, we can speculate that forests were small $\mathrm{C}$ sources in the early to mid-1800s. In the latter part of the 19th century, forests probably released great amounts of $\mathrm{C}$ as harvesting and land clearing increased throughout the end of the century, with huge wildfires unleashing $\mathrm{CO}_{2}$ through the early to mid-20th century. 
After this time, as forests became re-established on agricultural lands, fire suppression programs succeeded and fossil fuels took the place of fuelwood, the forests slowly became a sink of $\mathrm{C}$.

\subsection{USE OF FORESTS FOR FUELWOOD AND CURRENT NET C FLUX}

The history of forests in the temperate zone is inextricably linked with energy production and fossil fuel use. Much of the wood harvested from forests in the past in both Europe and the United States was burned as fuelwood in the home. Over $90 \%$ of harvested wood was burned as fuel as late as 1850 in the U.S., while Europe used about $30 \%$. Population growth continued, which led to local wood shortages that increasingly forced substitution of fossil fuels for fuelwood. Currently, fuelwood supplies under $10 \%$ of energy needs on these continents (Mather, 1990). That temperate forests are presently sequestering $\mathrm{C}$ is due directly to human preference of burning fossil fuels for energy (and thereby releasing $\mathrm{CO}_{2}$ into the atmosphere) rather than fuelwood.

\subsection{FUTURE}

Projections of C pools and fluxes (Birdsey et al., 1993; Turner et al., 1993; Heath and Birdsey, this volume) assuming no changes in climate indicate that temperate forests in the U.S. will remain a weak sink over the next $50 \mathrm{yr}$. However, the rate of sequestration is projected to decrease as harvest levels increase to meet growing demands for wood. Figure 3 indicates the general shape of the net $\mathrm{C}$ trends in the temperate forests of Europe and the United States. No climate change is assumed. The future range of uncertainty in the future is due purely to human effects. Increasing demand for wood may change the forests into a $\mathrm{C}$ source, but adoption of policies to sequester $\mathrm{C}$ such as afforestation may keep the forests as sinks. Most temperate forests are managed, so that influencing net $\mathrm{C}$ flux by forestry activities is easier to realize that in the tropical or boreal zones.

\section{Management Practices to Keep Temperate Forests a Sink}

European nations such as Germany have been considering forestry activities to maintain forests as C sinks. We present some of Germany's suggested management practices in this section. A summary of the options and the duration of their effects are listed in Table 2.

\subsection{CONSERVING FOREST (BIOMASS) RESOURCES}

In comparison to tropical and subtropical regions, the conditions for sustainable management of temperate forests are favorable. All efforts must be made to practice sustainable management over the entire region. 

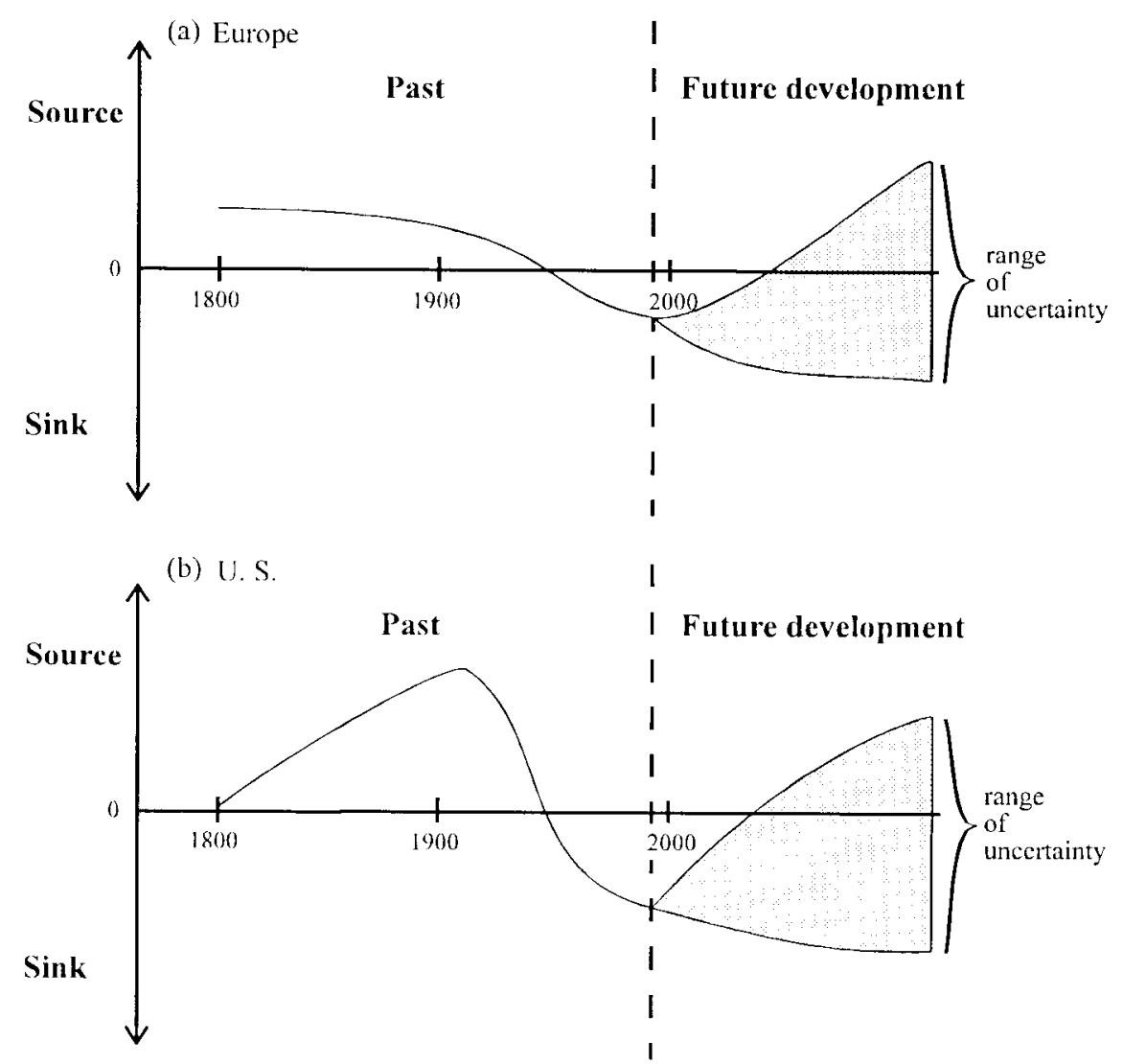

Figure 3. Historical development and suggested future changes of $\mathrm{C}$ in temperate forests in (a) Europe and in the (b) United States.

Existing forest biomass in temperate zones of Europe and North America is not endangered by deforestation, but may be by degradation. In highly industrialized regions forests are stressed by anthropogenic air pollution, leading to forest dieback. This problem can only be solved by measures outside the forestry sector through reduction of emissions. Stand density and stand age are increasing on average in most countries in the temperate region, which tends to increase the risk of disturbances. Climate change may result in an increase of pests, windfalls and fires. Therefore intensive efforts must be undertaken to manage forests in such a way that these disturbances are minimized. 


\begin{tabular}{|c|c|c|c|}
\hline Option & $\begin{array}{l}\text { short } \\
\text { term } \\
0-20 \text { yr }\end{array}$ & $\begin{array}{l}\text { mid } \\
\text { term } \\
21-60 \text { yr }\end{array}$ & $\begin{array}{l}\text { long } \\
\text { term } \\
>60 \mathrm{yr}\end{array}$ \\
\hline \multicolumn{4}{|l|}{ Conserving forest resources } \\
\hline \multirow{3}{*}{$\begin{array}{l}\text { - sustainable management } \\
\text { - protection against deforestation and degradation } \\
\text { - reduction of air pollution }\end{array}$} & $\mathrm{x}$ & $\mathrm{x}$ & $x$ \\
\hline & $\mathrm{x}$ & $\mathrm{x}$ & $\mathrm{x}$ \\
\hline & & $\mathrm{x}$ & $\mathrm{x}$ \\
\hline \multicolumn{4}{|l|}{ Increase of forest productivity } \\
\hline \multirow{4}{*}{$\begin{array}{l}\text { use optimum rotation period } \\
\text { change of tree species } \\
\text { enrichment planting } \\
\text { use of appropriate harvesting practices }\end{array}$} & $\mathrm{x}$ & $\mathrm{x}$ & $\mathrm{x}$ \\
\hline & & $\mathrm{x}$ & $\mathrm{x}$ \\
\hline & $\mathrm{x}$ & $\mathrm{x}$ & $x$ \\
\hline & $\mathrm{x}$ & $\mathrm{x}$ & $\mathrm{x}$ \\
\hline \multicolumn{4}{|l|}{ - soil properties } \\
\hline \multirow{4}{*}{$\begin{array}{l}\text { fertilization, amelioration } \\
\text { erosion protection } \\
\text { no full tree utilization } \\
\text { less slash burning }\end{array}$} & $\mathrm{x}$ & $\mathrm{x}$ & $\mathrm{x}$ \\
\hline & $x$ & $x$ & $\mathrm{x}$ \\
\hline & $\mathrm{x}$ & $\mathrm{x}$ & $\mathrm{x}$ \\
\hline & $\mathrm{x}$ & $\mathrm{x}$ & $\mathrm{x}$ \\
\hline \multicolumn{4}{|l|}{ - forest structures } \\
\hline \multirow{2}{*}{\multicolumn{2}{|c|}{$\begin{array}{l}\text { adapted and adaptable tree species } \\
\text { mixed stands }\end{array}$}} & $\mathrm{x}$ & $\mathrm{x}$ \\
\hline & & $\mathrm{x}$ & $\mathrm{x}$ \\
\hline \multirow{2}{*}{$\begin{array}{l}\text { regulation of age and space structure } \\
\text { underplanting }\end{array}$} & & $\mathrm{x}$ & $\mathrm{x}$ \\
\hline & $\mathrm{x}$ & $\mathrm{x}$ & $\mathrm{x}$ \\
\hline \multicolumn{4}{|l|}{ - silvicultural systems } \\
\hline \multirow{2}{*}{$\begin{array}{l}\text { transforming coppice into high forest systems } \\
\text { biomass conserving regeneration systems }\end{array}$} & & $\mathrm{x}$ & $\mathrm{x}$ \\
\hline & $\mathrm{x}$ & $\mathrm{x}$ & $\mathrm{x}$ \\
\hline \multicolumn{4}{|l|}{ Afforestation } \\
\hline \multirow{3}{*}{$\begin{array}{l}\text { natural succession } \\
\text { high forests } \\
\text { energy plantations }\end{array}$} & $\mathrm{x}$ & $\mathrm{x}$ & $\mathrm{x}$ \\
\hline & & $\mathrm{x}$ & $\mathrm{x}$ \\
\hline & $\mathrm{x}$ & $\mathrm{x}$ & $\mathrm{x}$ \\
\hline \multicolumn{4}{|l|}{ Improvement of wood utilization } \\
\hline \multirow{2}{*}{$\begin{array}{l}\text { - energy substitution } \\
\text { - material substitution (nonrenewable or energy } \\
\text { intensive material substitution) }\end{array}$} & $\mathrm{x}$ & $\mathrm{x}$ & $\mathrm{x}$ \\
\hline & $\mathrm{x}$ & $\mathrm{x}$ & $\mathrm{x}$ \\
\hline \multicolumn{4}{|l|}{ Waste management } \\
\hline \multirow{2}{*}{$\begin{array}{l}\text { - energy production from used forest products } \\
\text { - improved landfill }\end{array}$} & $\mathrm{x}$ & $x$ & $x$ \\
\hline & & $\mathrm{x}$ & $\mathrm{x}$ \\
\hline
\end{tabular}

Table 2. Options to manage the $\mathrm{C}$ budget using forestry related measures, and duration of effects. 


\subsection{INCREASE OR RESTORATION OF FOREST PRODUCTIVITY}

In terms of development dynamics, managed forests represent the aggradation phase of the forest ecosystem. Compared to mature natural forests, they are characterized by a lower amount of biomass but a high growth increment. Restricted harvesting would initially increase $\mathrm{C}$ stored in forests, but eventually growth would slow, as would $\mathrm{C}$ sequestration. In the long-term, harvesting forests at the optimum time and producing wood products and fuelwood as a substitute for fossil fuel might sequester a greater amount of total $\mathrm{C}$.

Because of past devastative practices in some regions still persistent an improved accumulation of $\mathrm{C}$ can also be achieved by different measures. The main activities are include increasing stand productivity and biomass, improvement of soil properties, improvement of forest structures, and transformation of coppice systems to high forest systems.

\subsection{AFFORESTATION}

One of the major options to increase $\mathrm{C}$ storage by forests is the afforestation of nonforested land. It is difficult to quantify the potential storage capacity for afforestation in temperate zones. Afforestation depends on the availability of agricultural land, which is related to the surplus of agricultural production, especially in Europe and North America. In Europe the total potential for conversion of farmland into forest land is estimated to be approximately 44 Mha. For the U.S., a biological potential of approximately $100 \mathrm{Mha}$ is estimated. The potential for the entire temperate zone remains uncertain. Other areas that could be used for afforestation are degraded and marginal lands as well as areas susceptible to erosion. Socioeconomic and ecological aspects must be considered when estimating afforestation potential.

Afforestation programs should consider that establishment of high forest is more efficient than energy plantations in terms of $\mathrm{C}$ storage and ecological aspects. The latter are preferable when wood has to be produced as substitute for fossil fuels. In any case, afforestation is only useful if a corresponding demand for wood products and energy exists or can be stimulated.

\subsection{IMPROVED USE OF WOOD}

The use of wood in the form of long-lived products including construction lumber and furniture, and the recycling of paper and paperboard are important options to increase $\mathrm{C}$ storage. In addition, using wood as an energy source contributes to the reduction of $\mathrm{CO}_{2}$ emissions by substitution of fossil fuels.

\subsection{WASTE MANAGEMENT}

In spite of efficient recycling, forest products will eventually become municipal waste. An optimal solution would be to use such waste in energy production as a substitute 
for fossil fuels. If that is not possible, waste could be stored in abandoned coal mines or in landfills in such a way that $\mathrm{CO}_{2}$ and $\mathrm{CH}_{4}$ emissions are minimized.

\section{Future Carbon under Climate Change}

Future $\mathrm{C}$ estimates for the temperate zone are quite uncertain if increasing atmospheric $\mathrm{CO}_{2}$ concentration and climate change are considered. Species migrations have been forecast for the temperate forests of the U.S. within the next 100 years (Davis and Zabinski, 1992; also see IPCC, 1990) and species extinctions suggested (Peters and Darling, 1985). If these forecasts are accurate, the area we describe as temperate forest will have to be redefined. Because of uncertainty of identifying the onset of climate change, we concentrate on phenomena known to occur: increasing $\mathrm{CO}_{2}$ concentration, air pollution, and evolution.

\section{1. $\mathrm{CO}_{2}$ EFFECTS ON THE CELL, LEAF, AND STAND LEVEL}

Direct effects of $\mathrm{CO}_{2}$ enrichment on plants are well documented. (E.g., see Eamus and Jarvis, 1989.) They include stimulation of photosynthesis, growth, increased fruit size and production, reduced transpiration and stomatal conductance, changes in interand intra-specific competition, and enhanced tolerance against air pollution. Such effects depend on light and sufficient nutrient supply and are utilized in " $\mathrm{CO}_{2}$ fertilization" of greenhouse plant production.

On the cell level, the enzymatic capacity to fix atmospheric $\mathrm{CO}_{2}$ will influence the total amount of $C$ that can be incorporated per time unit. Temperate deciduous tree species differ in their ability to activate the responsible enzyme. The photosynthetic $\mathrm{CO}_{2}$ uptake rates will be limited by the ability of most deciduous trees to translocate the assimilates to storage organs or to convert them into woody material or both.

On the leaf level, direct effects of $\mathrm{CO}_{2}$ concentration on stomatal aperture have often been reported for deciduous trees. Water loss via stomata can be reduced under the predicted $\mathrm{CO}_{2}$ concentration increase, resulting in increased water use efficiency on the leaf level. From this it follows that forests on drier sites under an unchanged precipitation regime will respond more favorably to $\mathrm{CO}_{2}$ enhancement. Alterations of stomatal density have been reported as a consequence of $\mathrm{CO}_{2}$-doubling, but there is still considerable debate on this subject. $\mathrm{CO}_{2}$ concentration increases as well as temperature increases will influence respiration of leaves. Compensation of respiration by photosynthesis at low photon flux densities have been reported for elevated $\mathrm{CO}_{2}$ concentrations. However, both possible effects are of minor importance if deciduous trees develop more leaves per individual, which may occur with increasing $\mathrm{CO}_{2}$ concentrations.

Competition between the same species as well as that between different species will depend on $\mathrm{CO}_{2}$ supply. Within a uniform single-species stand the capacity of the growing area will be reached earlier at high $\mathrm{CO}_{2}$ concentrations. Competition between different deciduous tree species will be influenced due to the fact that pioneer species 
respond differently from climax species. Our knowledge is restricted to the response of a few deciduous tree species during the juvenile phase of development.

Preliminary results (Dieter Overdieck, pers. communication) of mineral analysis of young maple (Acer pseudoplatanus L.) and beech (Fagus sylvatica L.) indicate that the enhancing effect of increasing $\mathrm{CO}_{2}$ concentration on plant growth and production will not be limited in soils of medium fertility because mineral concentrations of the tissues (C, N, P, K, Ca, Mg, Mn, Fe) can decrease at least to a certain degree without obvious negative effects on growth. Two ecological consequences of these effects on mineral contents should be noted: 1) with decreasing mineral concentration, the nutritive value of the food for herbivores decreases, and 2) for the same reason, microorganisms in the soil may decompose the litter more slowly and less effectively. However, since the absolute mineral amounts in the whole vegetation or in the single sampling are greater, it can be predicted that the flux rates of nutrients will increase in the biogeochemical cycles if the tropospheric $\mathrm{CO}_{2}$ concentration continues to increase in the coming decades. This also means that more minerals will be taken up from the soil. Therefore, nutrient-poor soils could become impoverished faster than before.

Considering all these uncertainties an enhancement factor for the effect of $\mathrm{CO}_{2}$ doubling on pool-size of deciduous forest can only be speculatively defined from case studies. It might range from 1.05 to 1.3 at the time when the preindustrial $\mathrm{CO}_{2}$ concentration is doubled.

\subsection{IMPACT OF AIR POLLUTION}

Currently terrestrial ecosystems receive considerable amounts of $\mathrm{N}$ compounds (up to $60 \mathrm{~kg}$ of $\mathrm{N} \mathrm{ha}^{-1} \mathrm{yr}^{-1}$ in Central Europe) from air pollution by dry and wet deposition. As humid ecosystems are naturally characterized by $\mathrm{N}$ deficiency, $\mathrm{N}$ deposition from the atmosphere will initially improve plant growth. Later it leads to nutritional imbalances and finally causes nutrient deficiency (e.g.: $\mathrm{Mg}$, Ca or $\mathrm{Zn}$ ) or predisposition to drought, frost or pests. Oligotrophic or ombrotrophic systems are at highest risk by nitrogen deposition. Persistent input of only $5 \mathrm{~kg} \mathrm{~N} \mathrm{ha}^{-1} \mathrm{yr}^{-1}$ will shift interspecific competition in a way that certain plant species may become completely suppressed.

A large number of growth observations have been made in individual stands. In Europe they have indicated increased growth rates, which have often been attributed to the high $\mathrm{N}$ deposition. Severe decline of tree stands due to air pollution has been observed on relatively small areas so that they have only an insignificant effect on the $C$ pools and fluxes of the entire forest zone. However, there is concern that air pollutants can cause nutrient imbalance in soils and adversely affect tree leaves and, thereby, affect the $\mathrm{C}$ budget in the long term.

\subsection{POSSIBLE EVOLUTIONARY CONSEQUENCES}

The shifts in the relation of $\mathrm{CO}_{2}$ to $\mathrm{O}_{2}$ that occurred during earth's history was an important feature for the evolution of plant and animal life. The doubling of 
tropospheric $\mathrm{CO}_{2}$ predicted to occur in the upcoming century will therefore have marked ecological consequences. These will be stronger in autotrophic than in heterotrophic organisms. Those with shorter generations will adapt to the changes faster than others with longer generations. Changes in host-pathogen relations are likely to occur, but co-evolution of both hosts and symbiotic partners is less likely.

\section{Research needs}

1. Continue monitoring forest biomass growth, disturbances, mortality and removal to improve database and time series for the estimation of forest biomass in temperate forests, particularly for Russia and China, detect $\mathrm{CO}_{2}$ fertilization effects in temperate forest ecosystems, obtain data and reduce uncertainties about $\mathrm{C}$ reservoirs and turnover, improve dynamic temperate forest ecosystem models, and better assess the fate of the sink potential and the change of ecological niches and distribution of species. The coordination of research efforts at all sites and on all forms of land use is a prerequisite for a reliable database that can be used by all working groups.

2. Questions about effects of increasing atmospheric $\mathrm{CO}_{2}$ concentration on various topics need to be studied. The topics include interactions of $\mathrm{CO}_{2}$ and temperature effects on water balance in forest ecosystems, effects of the nutritional conditions on the response to elevated $\mathrm{CO}_{2}$, and problems and limitations in upscaling $\mathrm{CO}_{2}$ enhancement experiments to natural conditions.

3. Investigate the effects of air pollution (including pollutants such as $\mathrm{O}_{3}, \mathrm{NO}_{x}, \mathrm{CH}_{4}$ ) on forest growth and health and $\mathrm{C} / \mathrm{N}$ interactions, along with other non-climate factors such as population growth.

4. Improve climate change scenarios and their application as modules for ecosystem impact models (including extreme events).

5. More research is needed on ecological processes that will affect $\mathrm{C}$ sequestration, including competition relations between different tree species by variation of site and succession stage, species adaptability (genetic potential), and host/symbiosis and host pathogen interactions.

\section{Summary}

Historically, temperate forests have been impacted greatly by human activity. The area covered by forest has decreased over the past millennia to about one half of its potential. Forests have been converted for agriculture, and for human habitation. During this conversion the forests were a $\mathrm{C}$ source.

New statistics from UN-ECE/FAO indicate that fellings and natural losses 
accounted for only 70 to $80 \%$ of the net annual increment in many of the temperate zone countries. Coupled with the historical outlook, it can be surmised that living vegetation of temperate forests at present is a sink of atmospheric $\mathrm{CO}_{2}$. Data are less consistent regarding forest soils. The annual removal of $\mathrm{C}$ in wood for products was approximately equal to the net storage in living biomass, indicating that harvesting and wood production plays an important role in these forests.

A large number of management options are available to further increase the fluxes from the atmosphere into the biomass pools. In the short term, rotation ages could be adopted that optimize $\mathrm{C}$ production, and land can be afforested. In the longer term ( 70 to $150 \mathrm{yr}$ ), it would be more efficient to harvest forest biomass and store $\mathrm{C}$ in wood products or produce energy as a substitute for energy produced from fossil fuels.

It will be difficult to improve the estimates of the future development of temperate forests as sinks or sources of $\mathrm{CO}_{2}$. The main constraints are related to the global change itself and to the negative and positive feedback mechanisms. Climate change has a potential of changing the pools and fluxes of $\mathrm{C}$ within the temperate forest system notably to increase decomposition rates, to cause forest decline and, thereby, to convert forests into a $\mathrm{C}$ source. The direct effect of $\mathrm{CO}_{2}$ on photosynthesis and growth $\left(\mathrm{CO}_{2}\right.$-fertilization) can also affect the budget calculations. It has been difficult to estimate that effect at the present time, and it will be increasingly difficult to forecast its impact on the long term.

\section{References}

Armentano, T.V., and Ralston, C.W.: 1980, The role of temperate zone forests in the global carbon cycle, Can. J. of Forest. Res. 10, 53-60.

Birdsey, R.A., Plantinga, A.J., and Heath, L.S.: 1993, Past and prospective carbon storage in United States forests, For. Eco. Manage. 58, 33-40.

Birdsey, R.A.: 1992, Carbon storage and accumulation in United States forest ecosystems, Gen. Tech. Rep. WO-59, U.S. Department of Agriculture, Forest Service, Washington, DC, 51 p.

Davis, M.B., and Zabinski, C.: 1992, Changes in geographical range resulting from greenhouse warming: effects on biodiversity in forests, in R. Peters and T. Lovejoy (ed), Global warming and biological diversity, Yale University Press, p. 297-308.

Deutscher Bundestag (ed.): 1990, Protecting the tropical forests: a high priority task, translated by $\mathrm{G}$. Woods-Schank, Bonn, Germany, $968 \mathrm{p}$.

Eamus, D., and Jarvis, P.G.: 1989, The direct effects of increase in the global atmospheric $\mathrm{CO} 2$ concentration on natural and commercial temperate trees and forests, Adv. Ecol. Res. 19, 1-55.

Heath, L.S., and Birdsey, R.A.: 1993, Carbon trends of productive temperate forests of the coterminous United States. J Air, Water, and Soil Pollution, In press.

IPCC: 1990, Climate change, the IPCC scientific assessment, University Press, $365 \mathrm{p}$. 
Kurz, W.A., Apps, M.J., Webb, T. M., and McNamee, P.J.: 1992, The carbon budget of the Canadian forest sector: Phase I., Forestry Canada, Northwest Region, Northern Forestry Centre, Edmonton, Alberta, Inf. Rep. NOR-X-326, 93 p.

Mather, A.S.: 1990, Global forest resources, Timber Press, Portland, OR, 341 p.

MacCleery, D.W.: 1992, American forests, a history of resiliency and recovery, USDA Forest Service in cooperation with Forest History Society, SF-450, 59 p.

Peters, R.L, and Darling, J.D.S.: 1985, The greenhouse effect and nature reserves, BioScience 35, 707-717.

Sedjo, R.A.: 1992, Temperate forest ecosystems in the global carbon cycle, Ambio 21, 274-277.

Turner, D.P., Lee, J.P., Koerpner, G.J., and Barker, J.R. (eds): 1993, The forest sector carbon budget of the United States: carbon pools and flux under alternative policy options, U.S. Environmental Protection Agency, Office of Research and Development, Washington, DC, EPA/600/3-93/093, 202 p.

UN-ECE/FAO: 1992, The forest resources of the temperate zones: general forest resource information, Vol. 1, New York, $348 \mathrm{p}$. 